\title{
A Method for Preparing Membrane Vesicles from Acetobacter aceti
}

\author{
By WALTER JUCKER, DANIEL STUDER AND LEOPOLD ETTLINGER* \\ Mikrobiologisches Institut, Eidgenössische Technische Hochschule, ETH-Zentrum, \\ CH-8092 Zürich, Switzerland
}

(Received 5 March 1987)

\begin{abstract}
Membrane vesicles were prepared from Acetobacter aceti by a method entailing growth in the presence of glycine, osmotic shock and lysozyme digestion. Energy-dependent transport of the amino acid valine could be demonstrated in the vesicles.
\end{abstract}

\section{INTRODUCTION}

For studies on acetate transport in Acetobacter aceti membrane vesicles that are unable to metabolize acetate were required. This paper describes the preparation and the characterization of such vesicles.

\section{METHODS}

Organism and cultivation. Acetobacter aceti NCIB 8554 (our no. LBGB 4114) was used. The growth medium contained (per litre of a $50 \mathrm{mM}$-potassium phthalate buffer, pH 5.5); $0.5 \mathrm{~g} \mathrm{KH}_{2} \mathrm{PO}_{4}, 0.5 \mathrm{~g} \mathrm{Na}_{2} \mathrm{HPO}_{4} .3 \mathrm{H}_{2} \mathrm{O}, 2 \mathrm{~g}$ $\left(\mathrm{NH}_{4}\right)_{2} \mathrm{SO}_{4}, 0.2 \mathrm{~g} \mathrm{MgSO}_{4} .7 \mathrm{H}_{2} \mathrm{O}, 10 \mathrm{mg} \mathrm{MnSO}_{4} .4 \mathrm{H}_{2} \mathrm{O}, 10 \mathrm{mg} \mathrm{NaCl}$ and $10 \mathrm{mg} \mathrm{FeCl}{ }_{3} .6 \mathrm{H}_{2} \mathrm{O}$. Sodium acetate $(30 \mathrm{mmol})$ was added as an organic substrate. The cultures were incubated for $15 \mathrm{~h}$ at $30^{\circ} \mathrm{C}$ in flasks containing baffles on a rotary shaker or in a 121 CHEMAP fermenter.

Cell-free extracts. At the end of the incubation, the cells were harvested by centrifugation $\left(7000 \mathrm{~g}, 10 \mathrm{~min}, 4^{\circ} \mathrm{C}\right)$ and washed in $0.2 \mathrm{M}$-saline. The pellet was resuspended in $0.1 \mathrm{M}$-Tris $/ \mathrm{HCl}$ buffer, $\mathrm{pH} 7.4(1 \mathrm{~g}$ wet weight in $10 \mathrm{ml}$ buffer) and pressed through a French pressure cell at $40 \mathrm{MPa}$. Cell debris was removed by a 15 min centrifugation at $20000 \mathrm{~g}$. The supernatant was called crude extract.

Protein determination. The protein content was determined by the Lowry method. For assay of intact cells, the method was modified (Herbert et al., 1971).

Enzyme activities. Citrate synthase (EC 4.1.3.7) was determined by the method of Weitzman (1969). Particulate glucose dehydrogenase (EC 1.1.99.17) was assayed by the method of Wood et al. (1962) with phthalate buffer replacing Mcllvain buffer.

Preparation of vesicles. Glycine $(2.7 \mathrm{~mm})$ and $10 \mathrm{mM}-\mathrm{MgSO}_{4}$ were added to a culture of exponentially growing cells. After a further $15 \mathrm{~h}$ incubation, the cells were recovered by centrifugation and washed twice with a solution of $150 \mathrm{~mm}-\mathrm{NaCl}$ and $10 \mathrm{mM}-\mathrm{MgSO}_{4}$. This was followed by an osmotic shock using the method of Neu \& Heppel (1965). The resulting sediment was resuspended in $0.1 \mathrm{M}$-potassium phosphate buffer, $\mathrm{pH} 7 \cdot 4$, with $10 \mathrm{mM}$ $\left(\mathrm{NH}_{4}\right)_{2} \mathrm{SO}_{4}$ as a stabilizer. Peptidoglycan degradation was initiated by the addition of $0.2 \mathrm{mg}$ lysozyme $\mathrm{ml}^{-1}$. After $8 \mathrm{~min}$ incubation, the resulting spheroplasts were stabilized with $20 \mathrm{~mm}-\mathrm{MgSO}_{4}$. Osmotic fragility was assayed by observation of the decrease of optical density at $546 \mathrm{~nm}$ after a tenfold dilution with water. For lysis of the spheroplasts and isolation of the vesicles, the methods of Kaback (1971) were followed. Unlysed cells and spheroplasts were removed by centrifugation at $200 \mathrm{~g}$ for $15 \mathrm{~min}$. The supernatant membrane preparation was homogenized with the aid of a gas-tight Hamilton syringe equipped with a 22 gauge needle. The homogenized vesicle suspension in $0.1 \mathrm{M}$-potassium phosphate buffer, $\mathrm{pH} 6.6$, with $20 \%(\mathrm{w} / \mathrm{v})$ sucrose was layered on top of a solution of $60 \%(\mathrm{w} / \mathrm{v})$ sucrose in the same buffer. After ultracentrifugation $(64000 \mathrm{~g}, 100 \mathrm{~min})$, the purified

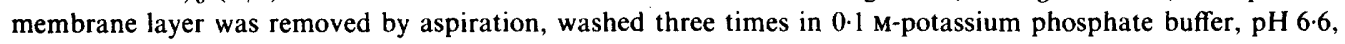
with $10 \mathrm{mM}$-EDTA and resuspended in the same buffer without EDTA. For storage the membrane preparation was frozen in batches in liquid nitrogen.

Uptake experiments in vesicles. These were done by the filtration method of Kaback (1974). The reaction volume was $50 \mu \mathrm{l}$ containing $80 \mu \mathrm{g}$ protein. The substrate was $\mathrm{L}-\left[\mathrm{U}^{-14} \mathrm{C}\right]$ valine $\left(9 \cdot 25 \mathrm{MBq} \mu \mathrm{mol}^{-1}\right)$. Potassium phthalate buffer $(50 \mathrm{mM}), \mathrm{pH} 6.6$, with $0.1 \mathrm{M}-\mathrm{LiCl}$ was used as washing buffer. 
Sample preparation for electron microscopy. Freeze-fractures were prepared by the method of Müller et al. (1980). For thin sections, the frozen samples were freeze-substituted by the method of Ebersold et al. (1981) and embedded in the plastic material K4M (Carlemalm et al., 1982). A Philips electron microscope was used.

\section{RESULTS AND DISCUSSION}

Attempts to prepare vesicles by standard methods (Kaback, 1971) failed. We were unable to obtain spheroplasts either using the penicillin (Lederberg, 1956) or the lysozyme/EDTA method (Mahler \& Fraser, 1956). It was therefore necessary to develop a special procedure. The method consisted of cultivation with the addition of glycine, osmotic shock and lysozyme digestion (for details, see Methods). The ensuing spheroplasts from lysozyme digestion are usually protected against lysis by a hypertonic solution of 0.3-0.5 M-sucrose (Kaback, 1971). This can, however, not be used with $A$. aceti since, for reasons which are not yet clearly understood, sucrose largely prevents lysozyme action. The same phenomenon was observed by Matsushita et al. (1981) with five different strains of acetic acid bacteria; their successful stabilizer was hypertonic saline. Bhandari \& Nicholas (1980) used $\mathrm{LiCl}$ for Nitrosomonas europaea. We used $\left(\mathrm{NH}_{4}\right)_{2} \mathrm{SO}_{4}$ and $\mathrm{MgSO}_{4}$. EDTA had no effect on lysozyme digestion. For the final steps from spheroplasts to vesicles, standard methods could be efficiently used. The results of the procedure were checked with activity tests of marker enzymes and with electron micrographs of thin-section and freezefracture preparations.

Enzyme tests of a membrane vesicle preparation of acetate-grown cells are shown in Table 1. Citrate synthase served as a cytoplasmic marker and the quinoprotein glucose dehydrogenase as a membrane-bound marker. The specific activity of citrate synthase decreased during the procedure of vesicle preparation to about $1 \%$ of its original value. The specific activity of glucose dehydrogenase increased at the same time to about $400 \%$ of its original value. This indicates that about $25 \%$ of the protein of whole cells was incorporated in the membrane vesicles of A. aceti. The corresponding figure for membrane vesicles of Escherichia coli is $15 \%$ (Kaback, 1971).

In electron micrographs of thin sections of cells grown in the absence (Fig. $1 a$ ) and in the presence (Fig. $1 b$ ) of glycine both types of cells appeared intact. Only the dense layer of the cell envelope between the outer and the cytoplasmic membranes appeared to be dissolved in the cells grown in the presence of glycine (Fig. 1b). This illustrates the known mode of action of glycine, i.e. the replacement of $L$ - and D-alanine during the synthesis of peptide subunits leading to a more loosely cross-linked peptidoglycan (Hammes et al., 1973).

Electron micrographs of freeze-fracture preparations (Fig. 2) observed in the direction of shading (arrows) revealed typical differences between concave and convex fracture faces. The concave (inner) faces had a regular structural pattern whereas the convex (outer) faces were irregularly covered with warty protuberances. This was observed with both whole cell (Fig. $2 a$, $b$ ) and vesicle preparations (Fig. $2 c$ ) indicating that the vesicles were right side out. A comparison of Fig. 2(a) with Fig. 2(b) showed that the surface of normally grown cells appears smooth and that of cells grown with glycine appears wrinkled.

In an uptake experiment with the amino acid valine the competence of the vesicles for energydependent transport was tested. Valine uptake was increased threefold by the addition of

\section{Table 1. Activity of marker enzymes during the preparation of vesicles of $A$. aceti}

Specific activities of the cytoplasmic marker citrate synthase and the membrane marker glucose dehydrogenase on harvesting, after an osmotic shock and in the vesicles. Each test was done in quadruplicate.

\begin{tabular}{|c|c|c|c|}
\hline \multirow[b]{2}{*}{ Enzyme } & \multicolumn{3}{|c|}{ Specific activity \pm SD (nkat $\mathrm{mg}^{-1}$ ) } \\
\hline & At harvest & $\begin{array}{l}\text { After osmotic } \\
\text { shock }\end{array}$ & $\begin{array}{l}\text { In the } \\
\text { vesicles }\end{array}$ \\
\hline $\begin{array}{l}\text { Citrate synthase } \\
\text { Glucose dehydrogenase }\end{array}$ & $\begin{array}{c}37 \pm 4 \\
0.26 \pm 0.05\end{array}$ & $\begin{array}{c}36 \pm 4 \\
0.29 \pm 0.06\end{array}$ & $\begin{array}{l}0.45 \pm 0.03 \\
1.07 \pm 0.10\end{array}$ \\
\hline
\end{tabular}



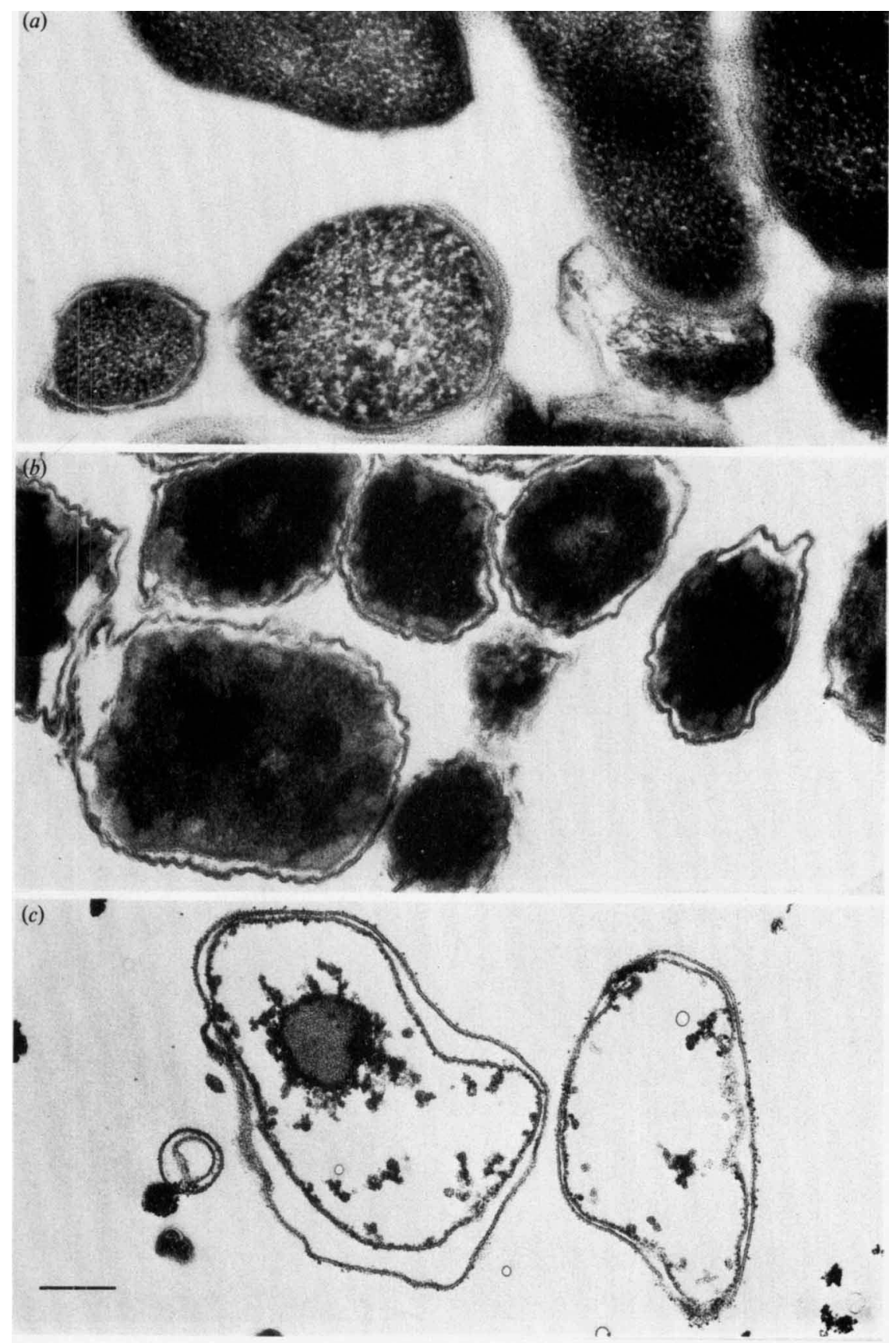

Fig. 1. Electron micrographs of $A$. aceti thin sections. (a) Whole cells grown without the addition of glycine; (b) whole cells grown with $2.7 \mathrm{~mm}$-glycine; $(c)$ a purified vesicle preparation. Bar, $0.2 \mu \mathrm{m}$. 

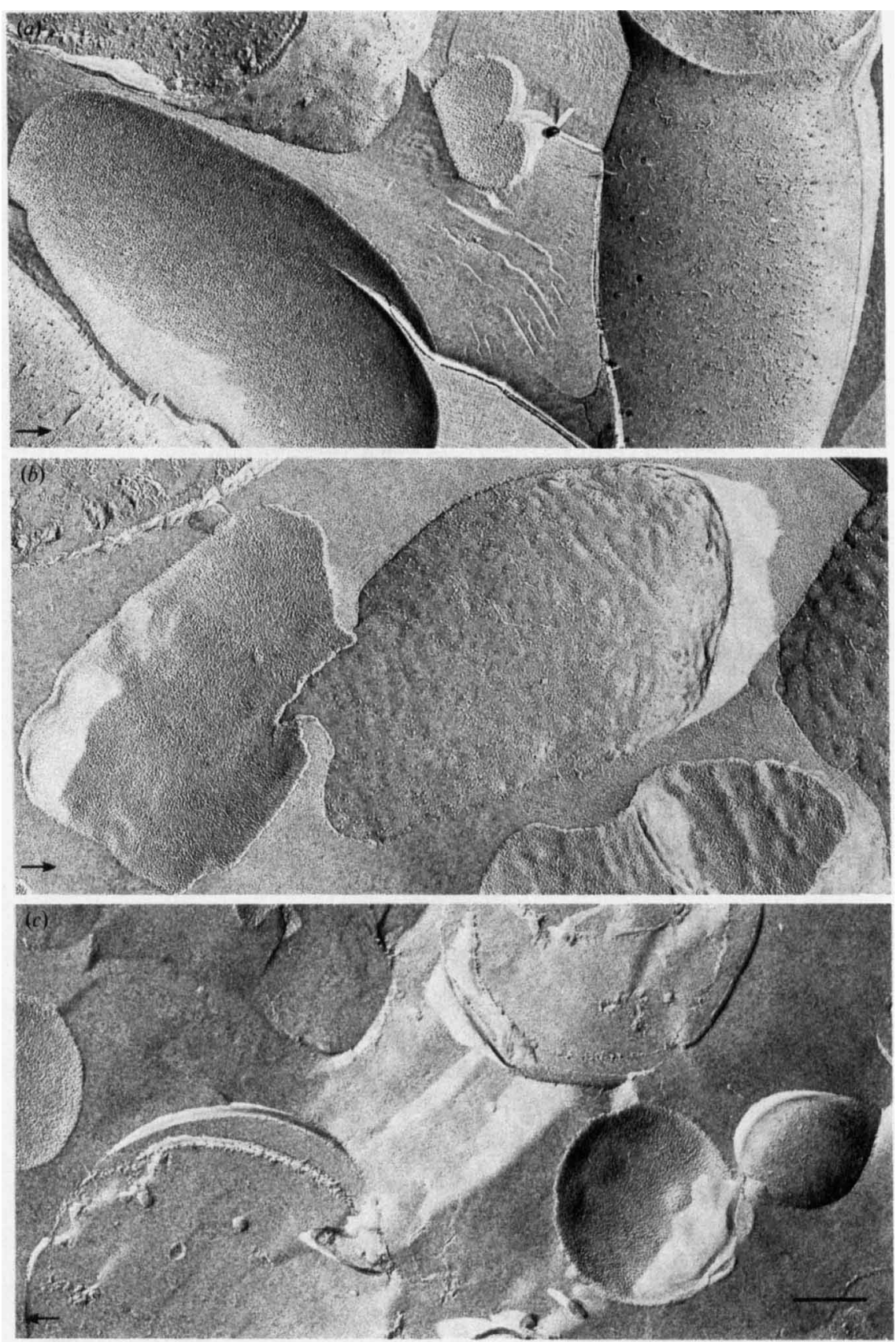

Fig. 2. Electron micrographs of $A$. aceti freeze-fractures. The arrows show the direction of shading. (a), $(b)$ and $(c)$ are as in Fig. 1. Bar, $0 \cdot 2 \mu \mathrm{m}$. 


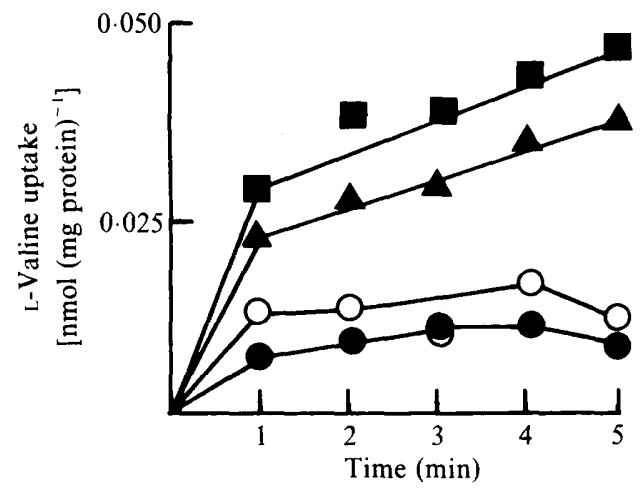

Fig. 3. Influence of different substrates and of an uncoupler on L-valine uptake in vesicles of acetategrown $A$. aceti. Membrane protein $(80 \mu \mathrm{g})$ was suspended in $50 \mu \mathrm{l} 0.1 \mathrm{M}$-potassium phosphate buffer,

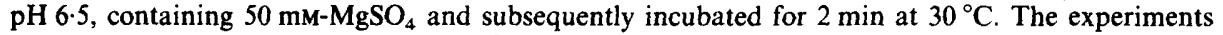
were started by the addition of $0.4 \mathrm{mM}-\mathrm{L}-\left[\mathrm{U}^{-14} \mathrm{C}\right]$ valine $\left(9.25 \mathrm{MBq} \mu \mathrm{mol}^{-1}\right)$. At appropriate times $1 \mathrm{ml}$ $50 \mathrm{~mm}$-phthalate buffer, $\mathrm{pH} 6.5$, containing $0.1 \mathrm{M}-\mathrm{LiCl}$ was added. The suspension was mixed and filtered through a membrane filter. Filters were washed with $3 \mathrm{ml}$ buffer and dried at $80^{\circ} \mathrm{C}$. The blanks were determined by adding radioactive substrate immediately before filtering the diluted vesicle suspension. Radioactivity was determined in a liquid scintillation counter. 0 , No energy source; $\Delta$, with $20 \mathrm{mM}$-DL-lactate; $\square$, with $20 \mathrm{~mm}$-glucose; $O$, with $20 \mathrm{~mm}$-DL-lactate and $5 \mathrm{~mm}-2,4-$ dinitrophenol.

glucose or of DL-lactate (Fig. 3). This effect was abolished by the addition of the uncoupling agent 2,4-dinitrophenol.

This work was supported by project 3.524-0.79 from the Swiss National Foundation for Scientific Research.

\section{REFERENCES}

Bhandari, B. \& Nicholas, D. J. D. (1980). Preparation of membrane vesicles in lithium chloride from cells of Nitrosomonas europaea. Analytical Biochemistry 109, 330-337.

Carlemalm, E., Garavito, R. M. \& Villiger, W. (1982). Resin development for electron microscopy and analysis of embedding at low temperature. Journal of Microscopy 126, 123-143.

Ebersold, H. R., LÜTHY, P., CoRdier, J. L. \& MÜlLER, M. (1981). A freeze-substitution and freeze-fracture study of bacterial spore structures. Journal of Ultrastructure Research 76, 71-81.

Hammes, W., SChleifer, K. H. \& KaNdler, O. (1973). Mode of action of glycine on the biosynthesis of peptidoglycan. Journal of Bacteriology 116, 10291053.

Herbert, D., Phipps, P. J. \& Strange, R. E. (1971). Determination of protein with the Folin-Ciocalteu reagent. Methods in Microbiology 58, 249-252.

KABACK, H. R. (1971) Bacterial membranes. Methods in Enzymology 22, 99-120.

KABACK, H. R. (1974). Transport in isolated bacterial membrane vesicles. Methods in Enzymology 31, 698703.
LEDERBERG, J. (1956). Bacterial protoplasts induced by penicillin. Proceedings of the National Academy of Sciences of the United States of America 42, 574-577.

MAHLER, H. R. \& FRASER, D. (1956). Reproduction of bacteriophage T3 in protoplasts of Escherichia coli, strain B. Biochimica et biophysica acta 22, 197-199.

Matsushita, K., Shinagawa, E., Adachi, O. \& Ameyama, M. (1981). Spheroplasts of acetic acid bacteria. Agricultural and Biological Chemistry 45, 1515-1518.

Müller, M., Meister, N. \& MoOR, H. (1980). Freezing in a propane jet and its application in freeze-fracturing. Mikroskopie 36, 129-140.

NEU, H. C. \& HEPPEL, L. A. (1965). The release of enzymes from Escherichia coli by osmotic shock and during the formation of spheroplasts. Journal of Biological Chemistry 240, 3685-3692.

Weitzman, P. D. J. (1969). Citrate synthase from Escherichia coli. Methods in Enzymology 13, 22-26.

Wood, W. A., Fetting, R. A. \& Hertlein, B. C. (1962). Gluconic dehydrogenase from Pseudomonas fluorescens. Methods in Enzymology 5, 287-291. 